May $2002 \quad$ • NREL/CP-520-31441

\title{
APIVT-Grown Silicon Thin Layers and PV Devices
}

\section{Preprint}

T.H. Wang, T.F. Ciszek, M.R. Page, R.E. Bauer, Q. Wang, and M.D. Landry

To be presented at the $29^{\text {th }}$ IEEE PV Specialists Conference New Orleans, Louisiana May 20-24, 2002

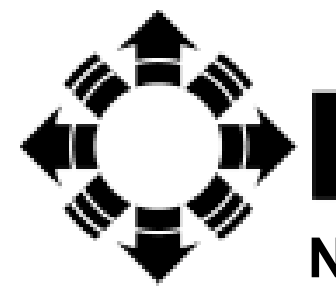

National Renewable Energy Laboratory

1617 Cole Boulevard

Golden, Colorado 80401-3393

NREL is a U.S. Department of Energy Laboratory

Operated by Midwest Research Institute $\bullet$ Battelle $\bullet$ Bechtel

Contract No. DE-AC36-99-G010337 


\section{NOTICE}

The submitted manuscript has been offered by an employee of the Midwest Research Institute (MRI), a contractor of the US Government under Contract No. DE-AC36-99G010337. Accordingly, the US Government and MRI retain a nonexclusive royalty-free license to publish or reproduce the published form of this contribution, or allow others to do so, for US Government purposes.

This report was prepared as an account of work sponsored by an agency of the United States government. Neither the United States government nor any agency thereof, nor any of their employees, makes any warranty, express or implied, or assumes any legal liability or responsibility for the accuracy, completeness, or usefulness of any information, apparatus, product, or process disclosed, or represents that its use would not infringe privately owned rights. Reference herein to any specific commercial product, process, or service by trade name, trademark, manufacturer, or otherwise does not necessarily constitute or imply its endorsement, recommendation, or favoring by the United States government or any agency thereof. The views and opinions of authors expressed herein do not necessarily state or reflect those of the United States government or any agency thereof.

Available electronically at http://www.osti.gov/bridge

Available for a processing fee to U.S. Department of Energy and its contractors, in paper, from:

U.S. Department of Energy

Office of Scientific and Technical Information

P.O. Box 62

Oak Ridge, TN 37831-0062

phone: 865.576 .8401

fax: 865.576.5728

email: reports@adonis.osti.gov

Available for sale to the public, in paper, from:

U.S. Department of Commerce

National Technical Information Service

5285 Port Royal Road

Springfield, VA 22161

phone: 800.553 .6847

fax: 703.605.6900

email: orders@ntis.fedworld.gov

online ordering: http://www.ntis.gov/ordering.htm

Printed on paper containing at least $50 \%$ wastepaper, including $20 \%$ postconsumer waste 


\title{
APIVT-GROWN SILICON THIN LAYERS AND PV DEVICES
}

\author{
T.H. Wang*, T.F. Ciszek, M.R. Page, R.E. Bauer, Q. Wang, and M.D. Landry \\ National Renewable Energy Laboratory, Golden, CO 80401 USA
}

\begin{abstract}
Large-grained (5-20 $\mu \mathrm{m})$ polycrystalline silicon layers have been grown at intermediate temperatures of $750^{\circ}-950^{\circ} \mathrm{C}$ directly on foreign substrates without a seeding layer by iodine vapor transport at atmospheric pressure with rates as high as $3 \mu \mathrm{m} / \mathrm{min}$. A model is constructed to explain the atypical temperature dependence of growth rate. We have also used this technique to grow high-quality epitaxial layers on heavily doped CZ-Si and on upgraded MG-Si substrates. Possible solar cell structures of thin-layer polycrystalline silicon on foreign substrates with light trapping have been examined, compared, and optimized by two-dimensional device simulations. The effects of grain boundary recombination on device performance are presented for two grain sizes of 2 and $20 \mu \mathrm{m}$. We found that $10^{4} \mathrm{~cm} / \mathrm{s}$ recombination velocity is adequate for $20-\mu \mathrm{m}$ grainsized thin silicon, whereas a very low recombination velocity of $10^{3} \mathrm{~cm} / \mathrm{s}$ must be accomplished in order to achieve reasonable performance for a $2-\mu \mathrm{m}$ grain-sized polycrystalline silicon device.
\end{abstract}

\section{INTRODUCTION}

One of the most attractive ways to achieve efficient and practical thin-silicon solar cells is to directly deposit large-grained poly-Si thin layers $(10-20 \mu \mathrm{m})$ on foreign substrates at a high rate without the need for a seeding layer. Atmospheric pressure iodine vapor transport (APIVT) of silicon is based on a disproportionation reaction between $\mathrm{Sil}_{2}$ and $\mathrm{Sil}_{4}$. It is a non-vacuum, openchamber deposition technique with potential for continuous processing, with low capital cost and no need for expensive effluent treatment [1].

Recent efforts on microcrystalline silicon solar cells with amorphous silicon technology have resulted in respectable efficiencies to be used as the bottom cell in a tandem structure, owing to a number of possible beneficial factors including a-Si passivating c-Si crystallites, hydrogen passivation, preferred orientation, and an intrinsic absorber. However, such cells may be difficult to make with high enough efficiencies for low-cost single junction products. In developing practical and efficient thin-silicon solar cells using the APIVT-deposited silicon layers, continued improvement in material properties and optimized device structures must be investigated. In this paper, we present our recent progress in material growth, defect passivation, and diagnostic device results. Using a 2D silicon device simulator MicroTec ${ }^{\circledR}$, we studied the quantitative effects of grain boundary recombination on device performance in addition to possible thin-silicon solar cell structures with light trapping and optimized device designs.

\section{POLY-SILICON GROWTH AND DEVICES}

With APIVT, grains as large as $5 \mu \mathrm{m}$ are obtained even at a temperature of $750^{\circ} \mathrm{C}$ [1]. As the deposition temperature is raised to $900^{\circ} \mathrm{C}$, grain size increases to about $20 \mu \mathrm{m}$. This is about ten times the grain size achievable by a typical chlorosilane-CVD process. A 20- $\mu \mathrm{m}$-grained poly-Si film approaches PV device quality if intragrain defects are not the limiting recombination mechanism. Passivation of intragrain defects (mostly stacking faults and twins) and grain boundaries by hydrogenation increased Hall mobility from $51 \mathrm{~cm}^{2} / \mathrm{V} \cdot \mathrm{s}$ to $76 \mathrm{~cm}^{2} / \mathrm{V} \cdot \mathrm{s}$. After passivation, we also observed improvement in the minority carrier diffusion length from internal quantum efficiency measurement in a finished device.

Typical growth is very fast (about $3 \mu \mathrm{m} / \mathrm{min}$ ) in a configuration with close source-substrate spacing, so that loss of silicon to the sidewall of the reactor is limited. In order to study the growth mechanism, a larger separation of source-substrate was used. Because of increased loss of silicon to the reactor wall, the growth rate was reduced to about $1 \mu \mathrm{m} / \mathrm{min}$, but we gained the ability to control the substrate temperature independently of the source temperature. Data in Fig.1 show atypically insensitive growth rates to substrate temperature at a constant source temperature of $1300^{\circ} \mathrm{C}$. Using a growth model that incorporates arrival of $\mathrm{Sil}_{2}$, surface migration of $\mathrm{Sil}_{2}$, and departure of $\mathrm{Sil}_{4}$, we can derive the relationship between growth rate and temperature.

From Wajda and Glang's [2] calculation of partial pressures of $\mathrm{Sil}_{2}$ and $\mathrm{Sil}_{4}$, we use the following approximation for the partial pressures:

$$
P\left(\mathrm{SiI}_{2}\right) \propto T ; \quad P\left(\mathrm{SiI}_{4}\right) \propto A-T^{2},
$$

where $A$ is a constant and $T$ is the substrate temperature. So pressure differences between the substrate and source locations would be:

$$
\Delta P\left(\mathrm{SiI}_{2}\right) \propto\left(T-T_{\text {source }}\right) ; \quad \Delta P\left(\mathrm{SiI}_{4}\right) \propto\left(T_{\text {source }}^{2}-T^{2}\right) .
$$

If there were no correlation between $\mathrm{Sil}_{2}$ and $\mathrm{Sil}_{4}$, we would have,

the rate of arrival for $\mathrm{SiI}_{2} \propto-\Delta P\left(\mathrm{SiI}_{2}\right)$,

and the rate of departure for $\mathrm{SiI}_{4} \propto \Delta P\left(\mathrm{SiI}_{4}\right)$. 


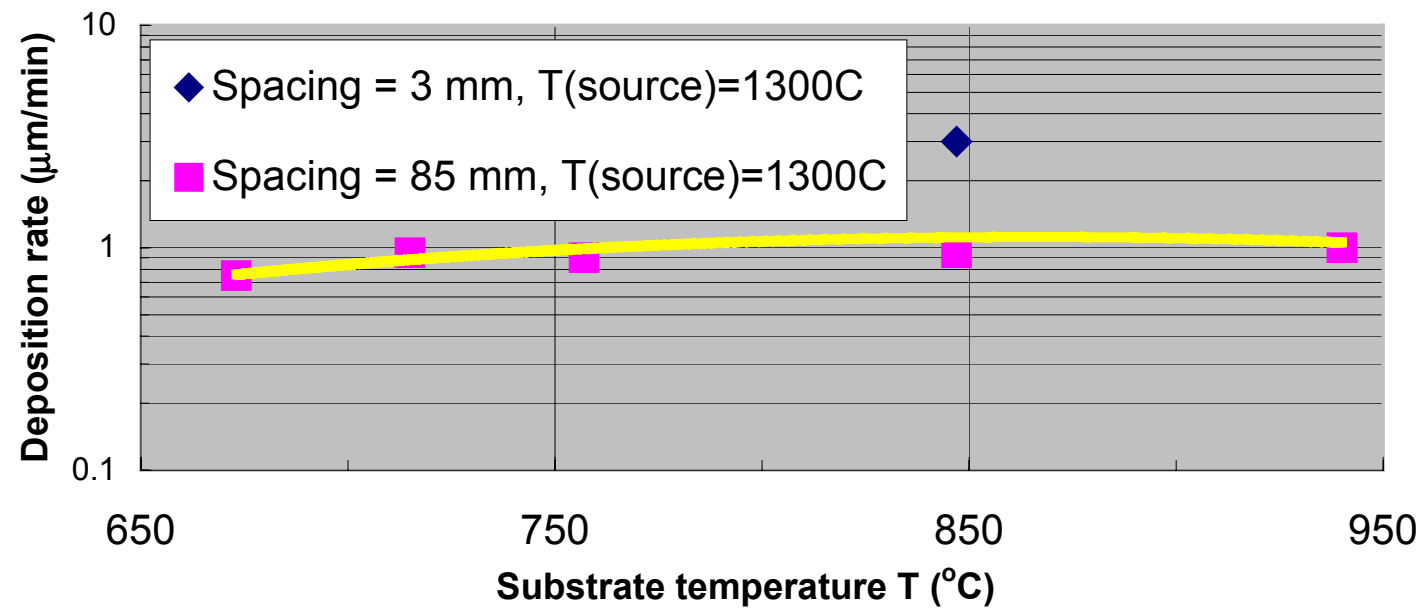

Fig. 1. Growth rate vs. temperature. The solid line is the fit by using $Q=0.27 \mathrm{eV}$.

The actual $\mathrm{Sil}_{2}$ arrival rate should also be proportional to $\mathrm{Sil}_{4}$ departure rate. In consideration of surface migration of $\mathrm{Sil}_{2}$ as the necessary step to find a suitable site for a silicon atom, we have the rate of deposition by the APIVT technique as:

$$
R \propto\left(T-T_{\text {source }}\right)\left(T_{\text {source }}^{2}-T^{2}\right) \exp \left(-\frac{Q}{k T}\right)
$$

where $Q$ is the activation energy for surface migration of $\mathrm{Sil}_{2}$. This correlation is used in Fig.1 to fit the experimental data, resulting in a $Q$ value of $0.27 \mathrm{eV}$. From the relationship, a simple explanation of this weak temperature dependence of growth rate is that as the substrate temperature is raised, surface migration is easier and thus the growth rate is higher. This is the normal temperature dependence as observed in a CVD process. However, as the substrate temperature is increased, the temperature difference between the source and substrate is decreased, resulting in a smaller free energy driving force and thus slower transport of silicon from source to substrate.

We fabricated a heterojunction solar cell with an a$\mathrm{Si}$ emitter on a polycrystalline Si layer grown by APIVT. A relatively low $V_{\text {oc }}$ of $0.47 \mathrm{~V}$ is observed [1], indicating that junction-shunting and minority-carrier recombination are still limiting the device performance. Such behavior has been widely observed on all as-grown polycrystalline silicon. Rather than bypassing this problem by doing complex single-crystal layer transfer procedures followed by a subsequent epitaxy process [3], we choose to improve the polycrystalline silicon material itself, taking advantage of the larger as-grown grain sizes compared to other available techniques. Twodimensional device simulation on grain boundary effects will later show that grain boundary passivation can be relaxed from a recombination velocity of $10^{3} \mathrm{~cm} / \mathrm{s}$ to a more attainable $10^{4} \mathrm{~cm} / \mathrm{s}$ when the grain size is increased from $2 \mu \mathrm{m}$ to $20 \mu \mathrm{m}$, in order to obtain an opencircuit voltage of $0.55 \mathrm{~V}$.
Effective photon absorption for thin layer silicon solar cells is another issue of equal importance frequently addressed by many authors. However, this may not be as serious a problem as people usually think. Calculation of light absorption by silicon of the usable AM1.5 spectrum in Fig. 2 indicates that if the layer thickness is less than $30 \mu \mathrm{m}$, a $15 \%$ current loss compared to an optically thick cell is to be expected, at which point one should employ effective light trapping. Fortunately, internal reflection at the back interface between a silicon layer and some foreign substrates usually is effective for this light-trapping purpose. For example, in Fig. 3, a bare $30 \mu \mathrm{m}$-thick APIVT-grown silicon layer on Corning LGA-139 ${ }^{\circledR}$ glass-ceramics (with excellent coefficient of thermal expansion match with $\mathrm{Si}$ ) reveals that only $0 \%$ $10 \%$ of incident light is transmitted through (lost by) the layer after taking into account front surface reflection and substrate absorption, as compared to a calculated loss of $15 \%-98 \%$ for the given thickness of silicon in a wavelength range of $850 \mathrm{~nm}-1100 \mathrm{~nm}$. This translates to a current loss less than $5 \%$. Even in this case, a reflective metal coating on the backside of the substrate would eliminate this small loss nevertheless.

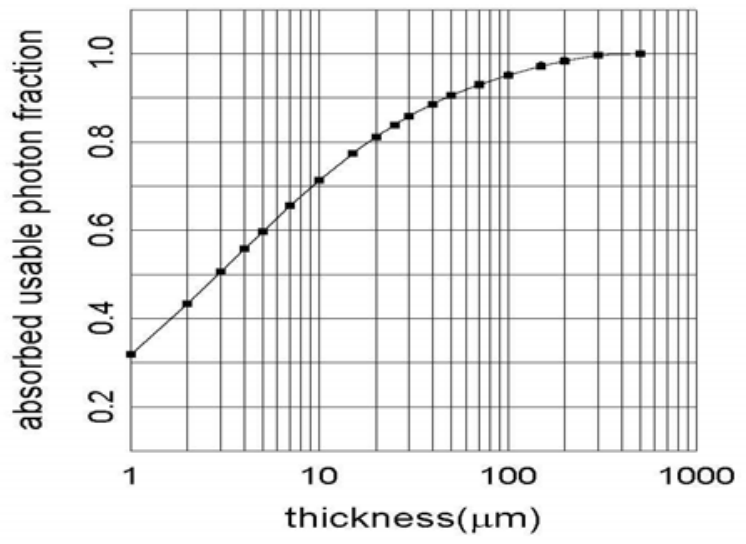

Fig.2. Calculated absorption of usable AM1.5 by silicon 


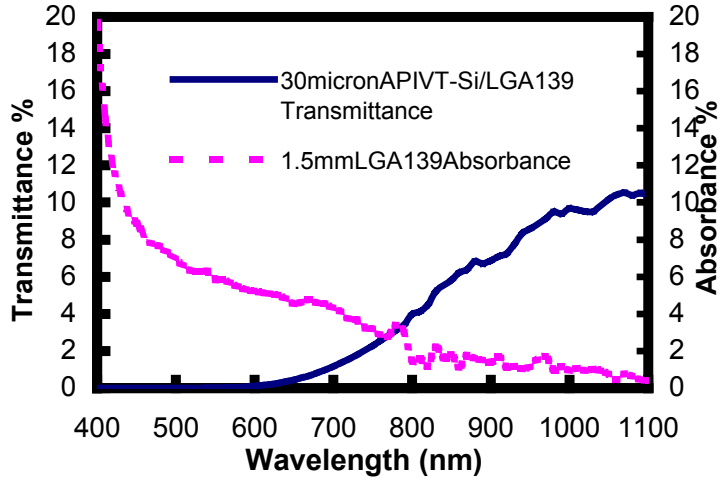

Fig. 3. Transmittance of a thin Si layer on LGA-139 ${ }^{\circledR}$.

\section{EPITAXIAL SILICON GROWTH AND DEVICES}

We obtain high-quality epitaxial growth on silicon substrates when a clean interface is maintained. This allows us to attain high-quality active layers on low-cost metallurgical-grade silicon substrates for solar cells or different doping layers on single crystal substrates for micro-electronic applications. Epitaxial layers also give us a measure of the solar cell performance limitations of this material independent of any grain-size effect.

A hetero-junction solar cell with an a-Si emitter was fabricated on a 20- $\mu \mathrm{m}$ thick epitaxial Si layer grown on a heavily doped single-crystal $\mathrm{Si}$ wafer $(0.0095 \Omega$-cm) (Fig. 4 top). In comparison to the similarly structured device on a CZ-Si control wafer, the APIVT-grown epitaxial $\mathrm{Si}$ layer demonstrates a thickness-limited 23 $\mathrm{mA} / \mathrm{cm}^{2}$ and the same $\mathrm{V}_{\mathrm{oc}}=0.53 \mathrm{~V}$ of the CZ-Si control cell. A diffused junction device on a thinner epitaxial layer on heavily doped CZ-Si shows an even slightly higher $\mathrm{V}_{\mathrm{oc}}$ of $0.56 \mathrm{~V}$ (Fig.4 middle). This result proves that the growth technique is capable of producing highquality material as long as grain boundaries are not involved. Successful epitaxial growth on upgraded metallurgical-grade silicon provided by Crystal Systems, Inc., was also obtained [4]. A test device with a diffused $p / n$ junction resulted in a less efficient cell, mostly due to poor $\mathrm{V}_{\text {oc }}$ (Fig.4 bottom). This might have something to do with impurity out-diffusion from the substrate because we used a relatively high temperature $\left(\sim 1100^{\circ} \mathrm{C}\right)$ procedure during growth. Using lower temperature below $900^{\circ} \mathrm{C}$ is possible for high-quality epitaxial growth, which will significantly reduce the impurity problem from an MG-Si substrate. TEM studies of the epitaxial layers on CZ-Si indicate a very low density of crystallographic

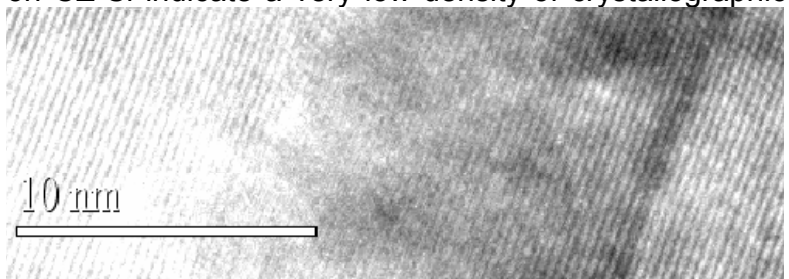

Fig. 5. High-resolution TEM image of an epitaxial silicon layer (left 4/5) on a CZ-Si substrate (right 1/5) defects (such as stacking faults, twins, and dislocations) compared to the substrate, as shown in Fig. 5.
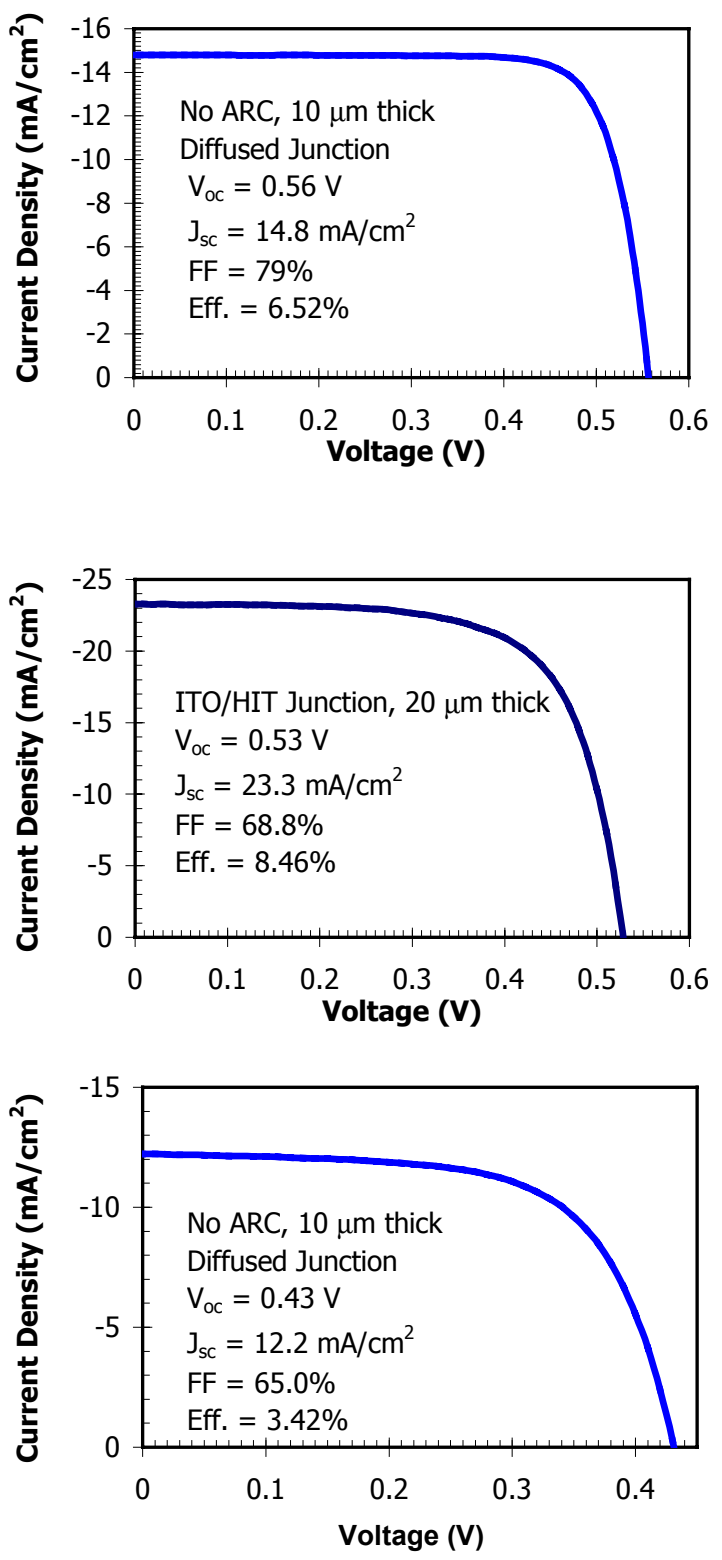

Fig. 4. I-V curves of devices made on various epitaxial silicon layers grown by APIVT. Top: HIT cell of a $20-\mu \mathrm{m}$ thick layer on heavily doped CZ-Si; Middle: diffused junction of a 10- $\mu \mathrm{m}$-thick layer on CZ-Si; Bottom: diffused junction of a $10-\mu m$-thick layer on MG-Si.

\section{D DEVICE SIMULATIONS}

MicroTec ${ }^{\circledR}$ is an affordable and robust 2D semiconductor process and device simulator [5] with many builtin, necessary physical models pertinent to silicon solar cells. Possible solar cell structures of thin-layer polycrystalline silicon on foreign substrates with light trap- 
ping have been examined, compared, and optimized by this two-dimensional device simulation. It is used here to quantitatively examine the effects of grain boundary recombination on device performances. Fig. 6 shows a sketch of a simple $\mathrm{N}^{+} / \mathrm{P} / \mathrm{P}^{+}$thin silicon model device with a total thickness of $20 \mu \mathrm{m}$ and an average grain size of $20 \mu \mathrm{m}$. The simulation domain consists of half of a grain (the shaded area). The grain boundary runs vertically across the junction on the right edge of the simulation domain. The calculated IV curves are given in Fig. 7 with recombination velocities at the grain boundary varying from $10^{2}$ to $10^{6} \mathrm{~cm} / \mathrm{sec}$. It is very clear that for a grain size of $20 \mu \mathrm{m}$, a recombination velocity lower than $10^{4} \mathrm{~cm} / \mathrm{s}$ is necessary to avoid significant loss of performance $\left(V_{o c} \geq 0.55 \mathrm{~V}\right)$. This velocity, however, has to be lowered to $10^{3} \mathrm{~cm} / \mathrm{s}$ for a grain size of $2 \mu \mathrm{m}$, as shown in Fig. 8.

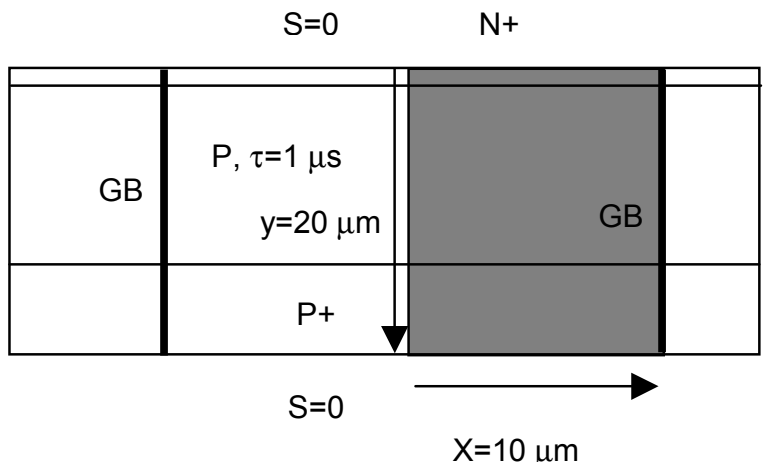

Fig. 6. Sketch of a polycrystalline silicon solar cell model having a thickness of $20 \mu \mathrm{m}$ and an average grain size of $20 \mu \mathrm{m}$. The shaded area is the simulation domain.

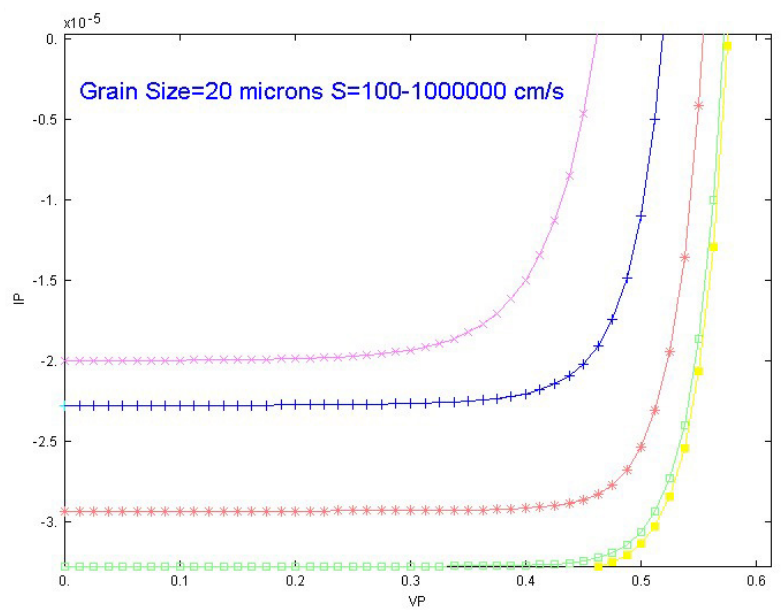

Fig. 7. Simulated IV curves for various recombination velocities at the grain boundary for a thin silicon solar cell with a grain size of $20 \mu \mathrm{m}$. From top to bottom: $10^{6}$, $10^{5}, 10^{4}, 10^{3}$, and $10^{2} \mathrm{~cm} / \mathrm{s}$.

\section{CONCLUSIONS}

Large-grained polycrystalline silicon is readily deposited with a high rate by the APIVT technique. The weak temperature dependence of growth rate is explained by a growth model derived from a three-step mechanism: arrival of $\mathrm{Sil}_{2}$, surface migration of $\mathrm{Sil}_{2}$, and departure of $\mathrm{Sil}_{4}$. This technique has also been used to grow high-quality epitaxial layers on heavily doped CZSi and on upgraded MG-Si substrates.

The effects of grain boundary recombination on device performances were examined by two-dimensional device simulation for two cases with grain sizes of 2 and $20 \mu \mathrm{m}$ respectively, and it is found that $10^{4} \mathrm{~cm} / \mathrm{s}$ recombination velocity is adequate for $20-\mu \mathrm{m}$ grain-sized thin silicon, whereas a much lower value of $10^{3} \mathrm{~cm} / \mathrm{s}$ must be accomplished for a $2-\mu \mathrm{m}$ grain-sized silicon. Passivating the grain boundaries to a recombination velocity below $10^{4} \mathrm{~cm} / \mathrm{s}$ seems to be a priority to achieve reasonable performances for the APIVT-grown silicon.

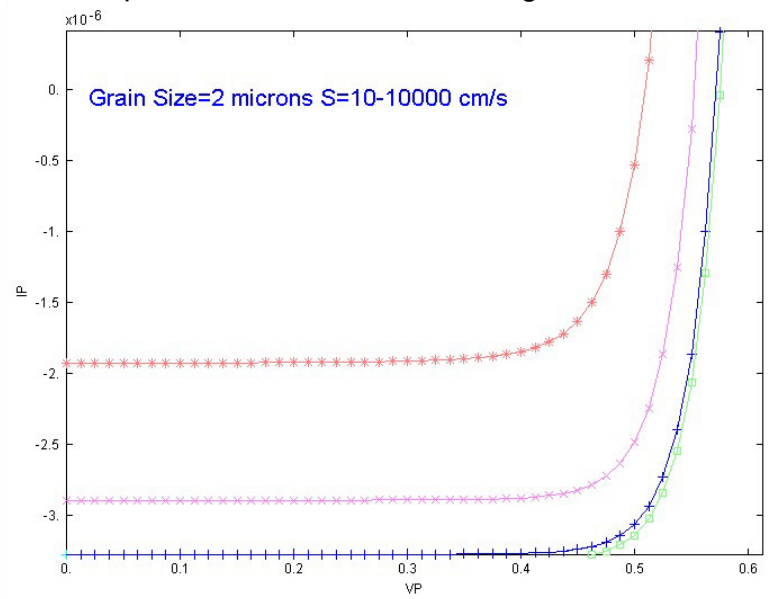

Fig. 8. Simulated IV curves for a 2- $\mu \mathrm{m}$-grained thin silicon solar cell. From top to bottom, for recombination velocities of $10^{4}, 10^{3}, 10^{2}$, and $10 \mathrm{~cm} / \mathrm{s}$, respectively.

\section{ACKNOWLEDGEMENTS}

We thank Prof. D. Ast of Cornel University for providing the Corning LGA $-139^{\circledR}$ substrates. Dr. Y.F. Yan, Dr. W.E. McMahon, and many others at the National Center for Photovoltaics are also gratefully acknowledged for material characterizations and helpful discussions. This work is supported by the U.S. Department of Energy under Contract No. DE-AC36-996010337 to the National Renewable Energy Laboratory.

\section{REFERENCES}

[1] T.H. Wang, T.F. Ciszek, M.R. Page, R.E. Bauer, M.D. Landry, Q. Wang, and Y.F. Yan, Proceedings of NREL PV Review Meeting, Denver, 2001.

[2] R. Glang and E.S. Wajda, Silicon, ed. J.J. Gilman, John Wiley \& Sons, New York, 1963, p.84.

[3] R.B. Bergmann, Recent Res. Devel. Crystal Growth Res., 1 (1999): 241-256.

[4] C.P. Khattak, D.B. Joyce, F. Schmid, T.F. Ciszek, M.R. Page, and M.I. Symko-Davies, to be published in Proceedings of the $17^{\text {th }}$ European Photovoltaic Solar Energy Conference.

[5] Siborg Systems Inc., MicroTec User's Manual. 


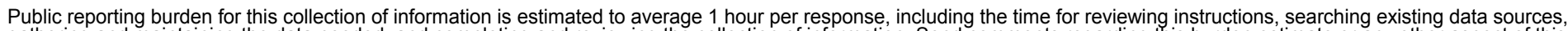

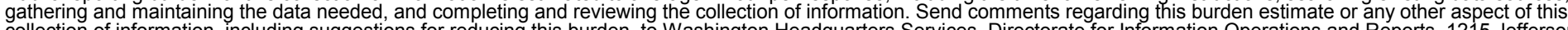
burden, to Washington Headquarters Services, Directorate for Information Operations and Reports, 1215 Jefferson Davis Highway, Suite 1204, Arlington, VA 22202-4302, and to the Office of Management and Budget, Paperwork Reduction Project (0704-0188), Washington, DC 20503.

\begin{tabular}{|l|l|l} 
1. AGENCY USE ONLY (Leave blank) & $\begin{array}{l}\text { 2. REPORT DATE } \\
\text { May } 2002\end{array}$ & $\begin{array}{l}\text { 3. REPORT TYPE AND DATES COVERED } \\
29^{\text {th }} \text { IEEE PVSC-Conference Paper } \\
\text { May 20-24 2002 }\end{array}$ \\
\hline
\end{tabular}

4. TITLE AND SUBTITLE APIVT-Grown Silicon Thin Layers and PV Devices: Preprint

6. Author(S) T.H. Wang, T.F. Ciszek, M.R. Page, R.E. Bauer, Q. Wang, and M.D. Landry

7. PERFORMING ORGANIZATION NAME(S) AND ADDRESS(ES) National Renewable Energy Laboratory 1617 Cole Blvd. Golden, CO 80401-3393

9. SPONSORING/MONITORING AGENCY NAME(S) AND ADDRESS(ES) National Renewable Energy Laboratory 1617 Cole Blvd.

Golden, CO 80401-3393

5. FUNDING NUMBERS PVP241011

8. PERFORMING ORGANIZATION REPORT NUMBER

10. SPONSORING/MONITORING AGENCY REPORT NUMBER

NREL/CP-520-31441

11. SUPPLEMENTARY NOTES

12a. DISTRIBUTION/AVAILABILITY STATEMENT

National Technical Information Service

12b. DISTRIBUTION CODE

U.S. Department of Commerce

5285 Port Royal Road

Springfield, VA 22161

13. ABSTRACT (Maximum 200 words): Large-grained $(5-20 \mathrm{~m})$ polycrystalline silicon layers have been grown at intermediate temperatures of $750^{\circ}-950^{\circ} \mathrm{C}$ directly on foreign substrates without a seeding layer by iodine vapor transport at atmospheric pressure with rates as high as $3 \mu \mathrm{m} / \mathrm{min}$. A model is constructed to explain the atypical temperature dependence of growth rate. We have also used this technique to grow high-quality epitaxial layers on heavily doped CZ-Si and on upgraded MG-Si substrates. Possible solar cell structures of thin-layer polycrystalline silicon on foreign substrates with light trapping have been examined, compared, and optimized by two-dimensional device simulations. The effects of grain boundary re-combination on device performance are presented for two grain sizes of 2 and $20 \mu \mathrm{m}$. We found that $10^{4} \mathrm{~cm} / \mathrm{s}$ recombination velocity is adequate for $20-\mu \mathrm{m}$ grain-sized thin silicon, whereas a very low recombination velocity of $10^{3} \mathrm{~cm} / \mathrm{s}$ must be accomplished in order to achieve reasonable performance for a 2- $\mu \mathrm{m}$ grain-sized polycrystalline silicon device.

14. SUBJECT TERMS: PV; atmospheric pressure iodine vapor transport (APIVT); microcrystalline silicon; solar cells; two-dimensional device; single junction; epitaxial layers; grain boundary; recombination velocity;

17. SECURITY CLASSIFICATION OF REPORT Unclassified
18. SECURITY CLASSIFICATION OF THIS PAGE Unclassified
19. SECURITY CLASSIFICATION OF ABSTRACT

Unclassified
15. NUMBER OF PAGES

16. PRICE CODE

20. LIMITATION OF ABSTRACT

UL 